\title{
Local extinction of Scinax caldarum, a treefrog in Brazil's Atlantic forest
}

\author{
Lucas Ferrante ${ }^{1}$, Ana Cristina Monteiro Leonel ${ }^{2}$, Renato Gaiga ${ }^{3}$, Igor L. Kaefer ${ }^{1,4}$ \& Philip M. \\ Fearnside ${ }^{1}$
}

${ }^{1}$ National Institute for Research in Amazonia (INPA), Manaus, Amazonas, Brazil

¿Universidade de São Paulo (USP), Instituto de Biociências, São Paulo, São Paulo, Brazi

${ }^{3}$ Biotropica Consultoria Ambiental, Poços de Caldas, Minas Gerais, Brazil

${ }^{4}$ Universidade Federal do Amazonas (UFAM), Manaus, Amazonas, Brazil

Here we report the local extinction of Scinax caldarum, an endemic tree frog species of the Brazilian Atlantic Forest. We also report a reduction of the geographic range of this species to less than $15 \%$ of the area in which it occurred 27 years earlier. We consider the excessive use of agrochemicals to be the main factor explaining the decline, including in farms with environmental certification. The local extinction of $S$. caldarum is a bioindicator of the severe impact of crops such as coffee and sugar cane, which heavily rely on agrochemicals. Stricter regulation of pesticides is needed to avoid damage to ecosystems and loss of biodiversity.

Keywords: Amphibia; Anura; conservation; endemism; Hylidae

$\mathrm{T}$ he tree frog Scinax caldarum (Fig. 1) typically occurs in open areas. Reproduction takes place in standing water and the tadpoles are exotrophic (Haddad et al., 2013). The species was described in 1969 by Bertha Lutz with the type locality being the municipality (county) of Poços de Caldas in the southern part of the state of Minas Gerais, Brazil. In 1982, six specimens of $S$. caldarum were collected in Alfenas municipality, also in

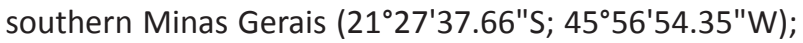
the specimens were deposited in the herpetological collection of the National Museum in Rio de Janeiro (catalogue numbers: 64807 - 64812). However, recent surveys in the municipality have not reported the species (D’Anunciação et al., 2013; Ferrante et al., 2015, 2017), suggesting that it is locally extinct.

Splitting of terrestrial and aquatic habitats with barriers imposed by land-use change represents one of the strongest drivers of amphibian declines, including those in the Atlantic Rainforest (Becker et al., 2007, 2010), and the quality and type of the agricultural matrix surrounding rainforest fragments constitutes an aggravating factor (Lion et al., 2014). Water bodies available for reproduction of anurans in the south of the Minas Gerais region are mainly located in forest

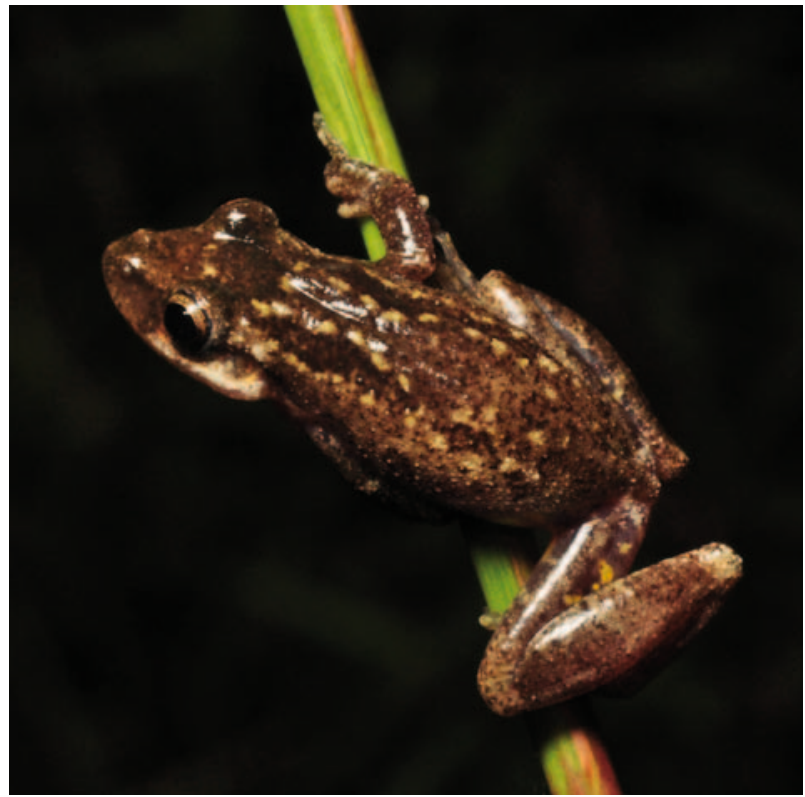

Figure 1. S. caldarum in Poços de Caldas municipality, Minas Gerais, Brazil (Photo by Renato Gaiga).

remnants that are often surrounded by inhospitable matrices with intense use of agrochemicals. This could be an insurmountable barrier preventing individuals of the species from reaching their reproductive environment.

A comprehensive study carried out in the municipality found that water bodies in forest remnants surrounded by coffee and sugarcane matrices have few or no habitat generalist species (Ferrante et al., 2017), reinforcing the hypothesis of local extinction of $S$. caldarum by agrochemical use in this landscape.

To verify the occurrence of $S$. caldarum in the Alfenas region, we sampled 20 forest fragments and 22 agricultural areas surrounding the fragments. The sampling followed the methodology described in Ferrante et al. (2017). The sampling covered the neighbouring municipalities of Areado and Alfenas, which are also locations that were within the area of 


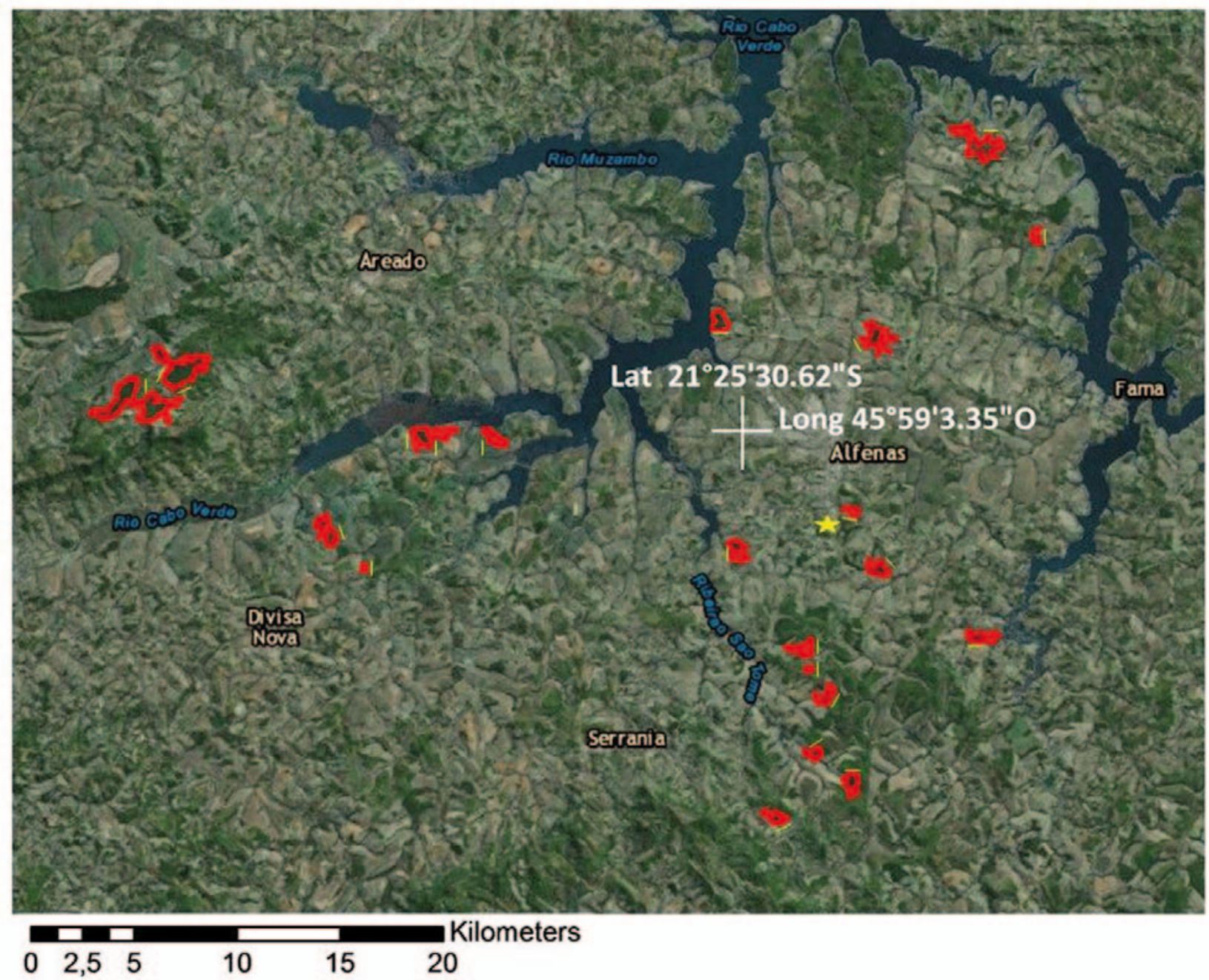

Figure 2. Landscape sampled in the Alfenas region: yellow star represents the collection point of S. caldarum in 1982; fragments circled in red represent sampled sites; yellow transects represent areas sampled in cultivated area.

occurrence of S. caldarum in 1982 (Fig. 2). The surveys were conducted between December 2011 and March 2012, which comprises the local rainy season (Roldão et al., 2012) and is the main amphibian breeding season in the Atlantic Forest (Haddad et al., 2013) including $S$. caldarum based on observations by ACML and RG in the type locality. Lutz (1973) shows S. caldarum has constant calling activity in all months of the year. Many of the sampled sites are located in farms growing sugarcane, coffee and pasture. Some of the farms have Rainforest Alliance and UTZ certifications, whilst others are not certified. Both sugarcane and coffee are crops with intensive use of pesticides and other agrochemicals. Only considering the certified farms, thirty-seven different pesticides are used in the sampled areas: Aureo, Blitz, Cantus, Abamectin, AzaMax, Lorsban $480 \mathrm{Br}$, Flumyzin, Glifos Plus, Glifosato Atanor, Galiagan, Goal, Zartan, Nimbus, Opera, Premier Plus, Prioriextra, Amistar WG, Durivo, Cuprozeb, Roundup, Sphere, Altacor, Warrant 700 WG, VERDADERO WG, Authority, Klorplan, Fegatex, Rovral, Aliete, Folicur, Stinger, Ally, K- Othrine 2P, Jaguar, Planador, Padron and Plenum.

No specimens of $S$. caldarum were found in Alfenas municipality despite a large sampling effort, including sampling in both forest remnants and in agricultural and other modified areas. We therefore consider this species to be locally extinct in Alfenas municipality. Although we have observed degradation and loss of native vegetation throughout the southern portion of Minas Gerais, including in certified farms (Fig. 2), generalist species, such as species of Scinax of the ruber group to which $S$. caldarum belongs (Haddad et al., 2013), have benefited from the loss of vegetation in forest remnants and have disappeared from fragments that are surrounded by matrices with a high proportion of agricultural crops with heavy agrochemical use (Ferrante et al., 2017). This strongly suggests that the local extinction is due to the harmful effect of the pesticides used in the landscape. The hypothesis of local extinction due to use of agrochemicals is further corroborated by the fact that other likely threats, such as mining, are restricted to the municipalities where the species still occurs (Caldas \& Poços de Caldas).

The total distribution area of S. caldarum in 1982 was $1228 \mathrm{~km}^{2}$, considering the population in Alfenas. However, we can consider that the current range of the species as only $184 \mathrm{~km}^{2}$, with the species occurring exclusively on the Poços de Caldas plateau (Fig. 3). These area measurements were performed based on polygons encompassing the recorded occurrences, 
Distribution in 1982

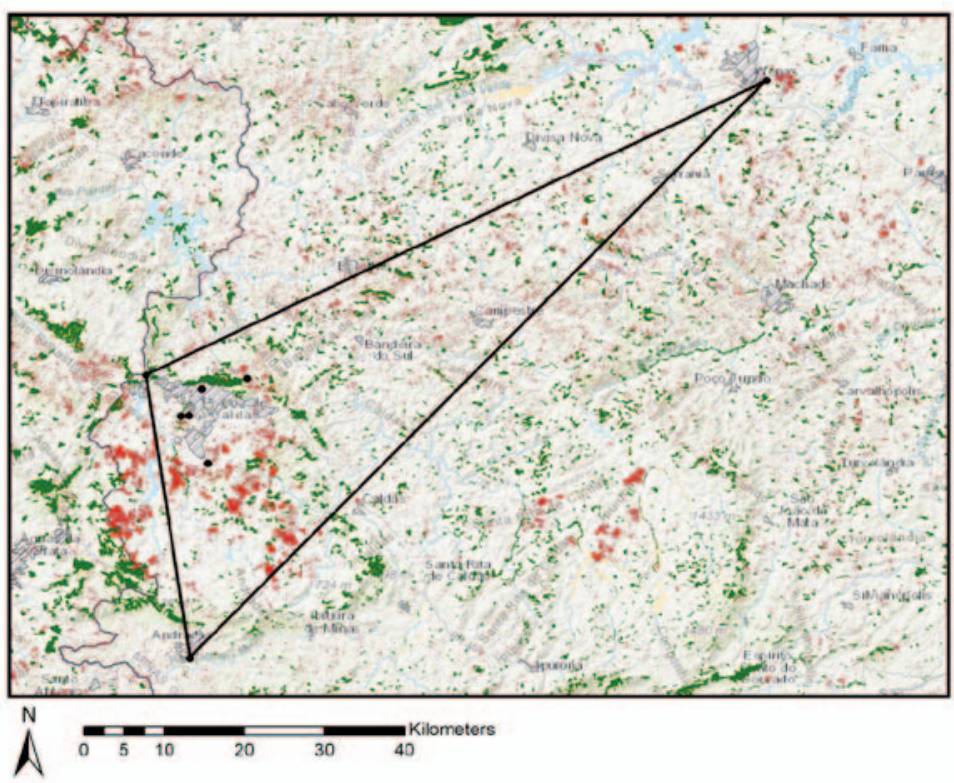

Distribution 2011-2012

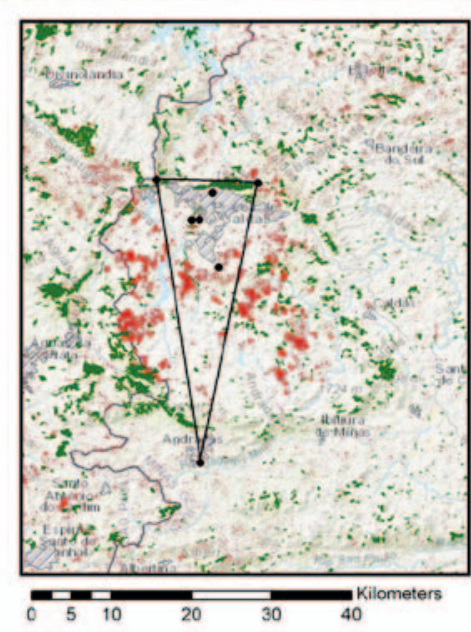

Forest fragments

Deforestation and vegetation cover loss (2001-2016).

Figure 3. Range of occurrence of S. caldarum in 1982 and 2011-2012 according to the most recent census.

following the methodology of the International Union for the Conservation of Nature (IUCN) and Brazil's Chico Mendes Institute of Biodiversity (ICMbio). This plateau is a circular formation with a mean diameter of about $33 \mathrm{~km}$; it is a result of orogenesis of volcanic origin in the Mesozoic era (Schorsche \& Shea, 1992). This relief favoured the isolation of several species of anurans that now are endemic, such as Bokermannohyla vulcaniae and Proceratophrys palustris (Cruz \& Feio, 2007; Neves et al., 2018). Although S. caldarum occurs in open or altered areas, imminent threats exist within the current range of this species on the Poços de Caldas Plateau. These include storage of toxic and radioactive mine tailings, new mining initiatives, and expansion of agricultural crops with heavy use of agrochemicals. In addition, habitat fragmentation is still a threat, and this could be aggravated by severe climate change in south-eastern Brazil. The region has experienced continuous water stress, with prolonged dry periods and absence of a rainy season (Geritana, 2016). Continued deforestation in the Amazon could exacerbate these changes by reducing the water recycling that is essential to providing water vapour that is transported by winds to Minas Gerais and other parts of southeastern Brazil (Zemp et al., 2014; Ferrante \& Fearnside, 2018). Indeed, climate change over the last decade in the southern portion of Minas Gerais (Getirana, 2016) may have also contributed to this extinction. However, while these events have been evident for more than 20 years since the last sighting of the species in the municipality of Alfenas, the same weather events have also been occurring in the municipalities where the species still occurs.

The IUCN listed Scinax caldarum as Least Concern (LC) in view of its wide distribution in the past, mistaken records of its geographic distribution, the tolerance of species to habitat modification, presumed large population, and because the population would be unlikely to be declining fast enough to qualify for listing in a more threatened category (IUCN, 2019). Based on the current threats being significantly greater than the threats that exterminated the population in Alfenas in less than 27 years, we consider that $S$. caldarum should be re-categorised as Endangered (EN) under criteria B1ab(i+iii) of the IUCN RedList (IUCN, 2012). The arguments are: the range is now less than $5000 \mathrm{~km}^{2}$; the population is endemic to the plateau; there is only one location of occurrence (sub criterion B1a); a continuous decline has been observed in the range of the species and in the quality of its habitat. Due to the harmful effects of mining on anurans (Sasaki et al., 2016), our results alert us to two needs: mining activities should be restricted through zoning in the area of occurrence of $S$. caldarum or other threatened species, mine tailings should be treated, and affected areas should be recovered. In addition, species in the state of Minas Gerais must be continuously monitored. This should be a responsibility of any entrepreneur who performs activities harmful to species within their area of occurrence, taking full responsibility for population declines or local extinctions owing to agricultural or mining activities. Creation of a protected area (conservation unit) in Poços de Caldas is urgently needed, and this should include both forest areas and the natural grasslands that are the habitat of generalist species that are endemic to the region. More rigid laws are needed to control the use of agrochemicals near permanent preservation areas ("APPs") in the Atlantic Forest Biome.

\section{ACKNOWLEDGEMENTS}

The authors are grateful to Maria Fernanda Sampaio, Thais Santos, Nathalia Klan Torres e Rafael Menegussi 
for invaluable help with fieldwork. We thank Manoela Woitovicz Cardoso for providing data from the collection of the National Museum of Rio de Janeiro and Cia. Agropecuária Monte Alegre for permission to access forest fragments within their properties. IDEA WILD provided field equipment; VALE/FAPEMIG and CNPq provided financial support.

\section{REFERENCES}

Becker, C. G., Fonseca, C. R., Haddad, C. F. B., Batista, R. F. \& Prado, P. I. (2007). Habitat split and the global decline of amphibians. Science 318, 1775-1777.

Becker, C. G., Fonseca, C. R., Haddad, C. F. B. \& Prado, P. I. (2010). Habitat split as a cause of local population declines of amphibians with aquatic larvae. Conservation Biology 24, 287-294.

Cruz, C. A. G. \& Feio, R. N. (2007). Endemismo em anfíbios em áreas de altitude na Mata Atlântica no sudeste do Brasil. In: Herpetologia no Brasil II. Sociedade Brasileira de Herpetologia, Belo Horizonte, Brazil. 354 pp.

D’Anunciação, P. E. R., Silva, M. F. V., Ferrante, L., Assis, D. S., Casagrande, T., Coelho, A. Z. G., Amancio, B. C. S., Pereira, T. R. \& Silva V. X. (2013). Forest Fragments Surrounded by Sugar Cane Are More Inhospitable to Terrestrial Amphibian Abundance Than Fragments Surrounded by Pasture. International Journal of Ecology 2013, 1-8.

Ferrante, L., Baccaro, F., Ferreira, E. B., Sampaio, M. F. O., Santos, T.N.S., Justino, R. C. \& Angulo A. (2017). The matrix effect: How agricultural matrices shape forest fragment structure and amphibian composition. Journal of Biogeography 44, 1-12.

Ferrante, L., Gaiga, R., Menegucci, R. C., Sampaio, M. F. O., Santos, T. N. S. \& Torres, N. K. (2015). Frogs and Toads in farms of Cia Monte Alegre and Forest Fragments in Alfenas, Areado and Conceição dos Ouros municipalities, Southern Minas Gerais, Brazil. The Field Museum, Chicago, USA.

Ferrante, L. \& Fearnside, P. M. (2018). Amazon sugarcane: A threat to the forest. Science 359, eaat4208.

Getirana, A. (2016). Extreme water deficit in Brazil detected from space. Journal of Hydrometeorology 17, 591-599.
Haddad, C. F. B., Toledo, L. F., Prado, C. P. A., Loebmann, D., Gasparini, J. L. \& Sazima I. (2013). Guide to the amphibians of the Atlantic Forest: Diversity and biology. Anolisbooks, São Paulo, Brazil.

IUCN (International Union for the Conservation of Nature and Natural Resources). (2012). IUCN Red List Categories and Criteria: Version 3.1. Avaliable at: http://www.iucnredlist. org/about/publication/assessment-process. (accessed 04 April 2019).

Lion, M. B., Garda, A. A. \& Fonseca, C. R. (2014). Split distance: A key landscape metric shaping amphibian populations and communities in forest fragments. Diversity and Distributions 20, 1245-1257.

Lutz, B. (1973). Brazilian species of Hyla. Austin \& London: University of Texas Press, 260p.

Mendenhall, C. D., Frishkoff, L. O., Santos-Barrera, G., Pacheco, J., Mesfun, E., Quijano, F. M., Ehrlich, P. R., Ceballos, G., Daily, G. C. \& Pringle R. M. (2014). Countryside biogeography of neotropical reptiles and amphibians. Ecology 95, 856-870.

Neves, M. O., Sugai, J. L. M. M., Rocha, S. B., Feio R. N. \& Santana, D. J. (2018). Distribution pattern of anurans from three mountain complexes in southeastern Brazil and their conservation implications. Anais da Academia Brasileira de Ciências 90, 1611-1623.

Roldão, A. F., Santos, J. G. \& Oliveira, L. A. (2012). Correlação entre as variáveis climáticas (altitude, temperatura e precipitação) na mesorregião Sul e Sudoeste de Minas Gerais - MG. Revista Geonorte 5, 515-525.

Sasaki, K., Lesbarrères, D., Beaulieu, C. T., Watson G. \& Litzgus J. (2016). Effects of a mining-altered environment on individual fitness of amphibians and reptiles. Ecosphere 7, e01360.

Schorsche, H. D. \& Shea, M. E. (1992). The regional geology of the Poços de Caldas alkaline complex: mineralogy and geochemistry of selected nephelin e syenites and phonolites. Journal of Geochemical Exploration 45, 25-51.

Zemp, D. C., Schleussner, C-F., Barbosa, H. M. J., van der Ent, R. J., Donges, J. F., Heinke, J., Sampaio, G. \& Rammig, A. (2014). On the importance of cascading moisture recycling in South America. Atmospheric Chemistry and Physics 14, 13337-13359.

Accepted: 12 June 2019 